\title{
KEPUTUSAN ORANG TUA DALAM MENGIJINKAN ANAK MENONTON FILM YANG MENGANDUNG UNSUR KEKERASAN
}

\author{
PARENTAL DECISIONS IN ALLOWING CHILDREN TO WATCH VIOLANCE \\ FILMS
}

\author{
Refrida Chandra Wardani \\ Departemen Promosi Kesehatan dan Ilmu Perilaku, \\ Fakultas Kesehatan Masyarakat, Universitas Airlangga, Surabaya. \\ Email: refridachandra@gmail.com
}

\begin{abstract}
Superhero film is a type of spectacle that is still widely consumed by children. Data from commonsense.org states that 68\% of superhero films which aired in 2011-2016 have PG-13 ratings (Parental Strongly Cautioned) that contain violence and can have an impact on child development. Children who often watch television or movies tend to less concentration, less attention to the environment, and imitate what is shown. This study aimed to determine related factors of parental decisions in allowing children to watch violence films. This research was a quantitative with cross sectional approach. By using simple random sampling technique, the samples of this research taken as many as 93 parents of $3^{\text {rd }}$ grade students at SDN Ketabang Surabaya. The data was collected by using questionnaire. This research used univariat and bivariate analysis. Most respondents are women (58.1\%), age 28-45 years (79.6\%), work as housewives (30.1\%), and head of household have high income (68.8\%). In relation to parental decisions in allowing children to watch violence films, most respondents have less knowledge (49.47\%), less supportive attitude (84.94\%), parents as personal reference in making decisions (68.82\%), unfulfilled facilities (52.69\%), and high family culture (69.9\%). Most respondents allow children to watch violence films (62.4\%). The chi square test showed that knowledge $(p=0.000)$, availability of facilities $(p=0.000)$, head of household income $(p=0.000)$, and family culture $(p=0.002)$ are significantly related to parental decisions in allowing children to watch violence films. While the variables of attitude $(p=0.096)$, personal references $(p=0.249)$, and age $(p$ $=0.853)$ are not significantly related to parental decisions in allowing children to watch violence films.
\end{abstract}

Keywords: children, parental decisions, superhero films, violence films

\begin{abstract}
Abstrak: Film superhero merupakan jenis tontonan yang masih banyak dikonsumsi oleh anak-anak. Data dari commonsense.org menyebutkan bahwa 68\% film superhero yang tayang pada tahun 20112016 memiliki rating PG-13 (Parental Strongly Cautioned) yang mengandung unsur kekerasan dan dapat berdampak pada perkembangan anak. Anak yang terlalu banyak menonton tayangan televisi ataupun film dapat tumbuh menjadi sosok yang sulit berkonsentrasi, kurang perhatian pada lingkungan sekitar, dan cenderung meniru apa yang ditampilkan. Tujuan penelitian ini adalah untuk mengetahui faktor yang berhubungan dengan keputusan orang tua dalam mengijinkan anak menonton film yang mengandung unsur kekerasan. Penelitian ini merupakan penelitian kuantitatif dengan pendekatan cross sectional. Dengan menggunakan teknik simple random sampling, didapatkan sampel sejumlah 93 orang tua/wali murid kelas 3 di SDN Ketabang Surabaya. Pengumpulan data dilakukan dengan menggunakan kuesioner. Analisis data dilakukan secara univariat dan bivariat. Sebagian besar responden adalah perempuan (58,1\%), berusia 28-45 tahun (79,6\%), bekerja sebagai Ibu Rumah Tangga (30,1\%), dan kepala keluarga memiliki penghasilan yang tinggi $(68,8 \%)$. Dalam kaitannya terhadap keputusan orang tua mengijinkan anak menonton film yang mengandung unsur kekerasan, responden memiliki pengetahuan yang kurang $(49,47 \%)$, sikap yang kurang mendukung $(84,94 \%)$, orang tua sebagai personal reference dalam mengambil keputusan (68,82\%), fasilitas yang tidak terpenuhi $(52,69 \%)$, dan culture keluarga yang tinggi (69,9\%). Sebagian besar responden mengijinkan anak menonton film yang mengandung unsur kekerasan $(62,4 \%)$. Hasil uji chi square menunjukkan bahwa variabel pengetahuan ( $\mathrm{p}$ $=0,000)$, ketersediaan fasilitas $(\mathrm{p}=0,000)$, penghasilan kepala keluarga $(\mathrm{p}=0,000)$, dan culture keluarga $(p=0,002)$ berhubungan secara signifikan terhadap keputusan orang tua dalam mengijinkan anak menonton film yang mengandung unsur kekerasan. Sedangkan variabel sikap $(p=0,096)$, personal references $(\mathrm{p}=0,249)$, dan umur $(\mathrm{p}=0,853)$ tidak berhubungan secara signifikan terhadap keputusan orang tua dalam mengijinkan anak menonton film yang mengandung unsur kekerasan.
\end{abstract}

Kata kunci: anak-anak, keputusan orang tua, film superhero, film kekerasan 


\section{PENDAHULUAN}

Anak adalah masa depan serta generasi penerus cita-cita bangsa. Masa anak-anak adalah salah satu fase yang pada fase ini anak mengalami masa perkembangan yang akan menentukan bagaimana anak tersebut pada fase berikutnya. Usia anak merupakan usia strategis dan lebih mudah terpengaruh, baik dari lingkungan dengan kontak langsung maupun media elektronik. Beberapa faktor yang dapat memengaruhi perkembangan anak diantaranya adalah orang tua, guru, teman, dan tayangan film/ televise (Bandura, 1963) (Hernawati, 2011). Saat nak-anak memiliki tingkat keterpaparan yang tinggi terhadap media, maka media memiliki akses dan waktu yang lebih besar untuk membentuk sikap dan tindakan anak-anak daripada orang tua atau guru. Media dapat menggantikan peran orang tua dan guru sebagai pendidik, panutan, dan sumber informasi utama tentang dunia dan bagaimana seseorang berperilaku di dalamnya (American Academy of Pediatric Council on Communications and Media, 2009).

Film merupakan alat komunikasi efektif bila dibandingkan dengan media lainnya, karena menonton film dapat memberikan gambaran kognitif dari sebuah tindakan. Kemudahan akses dalam menonton tayangan film menantang orang tua untuk lebih selektif dalam memilih tayangan yang boleh atau tidak boleh dilihat oleh anak. Berdasarkan penelitian Yayasan Pengembangan Media Anak (YPMA) yang bekerja sama dengan UNICEF pada tahun 2006 menunjukkan bahwa jumlah jam anak menonton tayangan film dan televisi pada usia SD berkisar 30-35 jam seminggu. Padahal, penelitian Guntarto tahun 2000 menunjukkan bahwa anak yang terlalu banyak menonton tayangan televisi ataupun film dapat tumbuh menjadi sosok yang sulit berkonsentrasi, kurang perhatian pada lingkungan sekitar, dan cenderung meniru apa yang ditampilkan.

Studi Yayasan Kesejahteraan Anak Indonesia (YKAI) yang bekerja sama dengan Balitban Deppen tahun 1995 menunjukkan bahwa adegan anti sosial lebih dominan (52\%) dalam film kartun bertemakan kepahlawanan dibandingkan adegan prososial (48\%). Kategori antisosial tersebut meliputi perkataan kasar, pembunuhan, perkelahian, pencurian, peperangan, pemukulan, penghinaan, dll. Unsur-unsur negatif dalam film tersebut dapat berpengaruh terhadap perilaku anak karena perilaku seseorang dapat terbentuk sebagai proses peniruan terhadap apa yang dilihat. (Bandura, 1963) Tayangan televisi, khususnya tayangan kekerasan dapat menyebabkan perilaku agresif, mimpi buruk, dan takut dirugikan. Menonton tayangan kekerasan juga dapat menyebabkan anak yang menontonnya kurang memiliki empati terhadap orang lain.

Data Komnas Perlindungan Anak yang dimuat dalam Buletin Studia edisi 319/ tahun ke 7/11 september 2006 melaporkan bahwa pada tahun 2006 setidaknya ada 7 kasus kekerasan yang dilakukan oleh anak usia 6-11 tahun yang terjadi akibat menonton tayangan smackdown. Salah satu kasusnya terjadi di Kota Surabaya. Korban kekerasan adalah Angga Rakasiwi, siswa SD 7 Babakan Surabaya yang mendapat lima jahitan di kening karena meniru tayangan smackdown.

Peran orang tua sangat dibutuhkan dalam membimbing anak memanfaatkan tayangan yang ada di televisi. Salah satu cara yang dapat dilakukan adalah dengan melihat rating/peringkat tayangan film yang akan ditonton oleh anak. Rating/ peringkat film diputuskan baik oleh MPAA atau lembaga sensor film Indonesia untuk membantu orang tua memastikan apakah film yang akan ditonton sesuai dengan usia anak mereka.

Pembatasan tayangan film atau pemberian rating film sudah diputuskan oleh Dewan Penilaian yang dikenal sebagai Classification and Rating Administration (CARA). Dewan ini beroperasi di bawah MPAA dan National Association of Theater Owners (NATO) memberikan kategori pada film menjadi 5 kategori yaitu, G (General Audiences), PG (Parental Guidance Suggested), PG-13 (Parental Strongly Cautioned), R (Restricted), dan NC-17 (Noone 17 and Under Admitted). Di Indonesia melalui lembaga sensor film membuat penilaian sendiri yang tetap mengadopsi dari MPAA untuk seluruh tayangan, baik 
film maupun program televisi. Peringkat tersebut dibagi 5 level yaitu A/SU (Anak/ Semua Umur), BO/A (Bimbingan orang tua/anak, batasan usia $4 \mathrm{~s} / \mathrm{d} 7$ tahun), BO (Bimbingan Orang tua, batasan usia anak $5 \mathrm{~s} / \mathrm{d} 12$ tahun), BO/RR (Bimbingan Orang tua/Remaja, usia $13 \mathrm{~s} / \mathrm{d} 16$ tahun), dan yang terakhir D (Dewasa, batasan usia 17 tahun ke atas).

Rating PG-13 (Parental Strongly Cautioned) adalah salah satu rating yang menunjukkan bahwa tayangan film/televisi mengandung unsur kekerasan, sensualitas, kegiatan orang dewasa, bahasa, atau unsur lainnya yang tidak layak ditonton oleh anakanak. Orang tua harus memberikan larangan tegas atau memberikan pendampingan kepada anak usia di bawah 13 tahun yang menonton tayangan film/televisi dengan rating PG-13. Hasil penelitian Safitri dkk pada tahun 2013 menunjukkan bahwa sebagian besar orang tua menerapkan pola asuh demokratis $(63,5 \%)$. Pola asuh demokratis menunjukkan bahwa meskipun orang tua memberikan batasan tentang apa yang boleh dan tidak boleh ditonton, anak tetap diberikan kebebasan untuk menentukan dan bertanggung jawab terhadap film yang ditonton.

Orang tua sebagai tempat pertama anak berinteraksi sebelum berinteraksi dengan orang lain mempunyai kewajiban untuk memantau proses tumbuh kembang anak juga harus dapat memfilter tontonan anak. Anak dapat menonton merupakan faktor dari akses yang diberikan oleh orang tua. Penting bagi orang tua dalam memahami sistem rating film ini, agar anak mendapat tontonan dengan konten yang pantas mereka konsumsi. Sehingga dapat meminimalisir salah satu potensi terjadi nya kekerasan dan kenakalan pada anak. Penelitian ini bertujuan untuk mengetahui faktor-faktor yang berhubungan dengan keputusan orang tua dalam mengijinkan anak menonton film yang mengandung unsur kekerasan.

\section{METODE}

Penelitian ini merupakan penelitian kuantitatif, dengan menggunakan instrumen kuesioner yang diberikan kepada responden.
Penelitian ini menggunakan metode sampel yang dipilih dari populasi tanpa memperhatikan adanya strata atau disebut dengan metode sample random sampling. Pengambilan data dilakukan dengan menggunakan pendekatan cross sectional.

Jumlah populasi secara keseluruhan dalam penelitian ini berjumlah 121 orang. Sampel menggunakan 93 santri putri orang tua/wali murid kelas 3 SD. Penelitian dilakukan di SDN Ketabang Surabaya. Metode pengumpulan data pada penelitian ini dibedakan menjadi dua, yaitu data primer dan data sekunder. Data primer pada pembuatan artikel ini, menggunakan kuesioner. Data sekunder dalam pembuatan artikel ini didapatkan dari literatur, artikel, jurnal, situs di internet yang berkenaan dengan penelitian yang dilakukan. Sebelum melakukan penelitian untuk terjun secara langsung di lapangan, penelitian ini telah lolos uji etik pada komisi etik di Fakultas Kesehatan Masyarakat Universitas Airlangga.

Penelitian ini menggunakan teori WHO sebagai referensi kerangka konsep dengan melibatkan faktor pemikiran dan perasaan (thoughts and feeling), adanya referensi dari seseorang yang dipercayai (personal references), sumber daya (resource) yang tersedia sebagai pendukung juga sosio budaya (culture). Variabel bebas penelitian meliputi pengetahuan, sikap, referensi dalam mengambil keputusan, usia, penghasilan, ketersediaan fasilitas, budaya di keluarga. Variabel terikat penelitian adalah keputusan orang tua dalam mengijinkan anak menonton tayangan film yang mengandung unsur kekerasan.

Setelah data terkumpul, data diolah melalui beberapa tahapan yaitu sebagai berikut: editing data, koding data, entry data, dan yang terakhir adalah tabulasi silang. (Notoatmodjo, 2010) Analisis data yang akan dijadikan acuan pembuatan artikel ini menggunakan uji statistik univariat dan uji statistik bivariat dengan chi square $(\alpha=5 \%)$. Hal tersebut bertujuan untuk mengetahui faktor yang berhubungan dengan keputusan orang tua dalam mengijinkan anak menonton film yang mengandung unsur kekerasan. 


\section{HASIL PENELITIAN}

Sekolah Dasar Negeri (SDN) Ketabang Surabaya merupakan salah satu sekolah negeri di antara 359 sekolah dasar negeri yang ada di Surabaya tepatnya di kelurahan Ketabang kecamatan Genteng. SDN Ketabang merupakan sekolah gratis pemerintah yang tidak memungut biaya dengan fasilitas memadai. Semua Biaya Operational Sekolah berasal dari BOPDA, BOSNAS, dan dana dekonsentrasi yang di-manage sedemikian detail. Penilaian Pendidikan di SDN Ketabang Surabaya sesuai dengan standar nasional Pendidikan yang berkaitan dengan mekanisme, prosedur dan instrument hasil belajar peserta didik.

Tabel 1. Karakteristik Responden di SDN 3 Ketabang, Surabaya

\begin{tabular}{lcc}
\hline Karakteristik & N & \% \\
\hline Usia & & \\
$28-45$ thn & 74 & 79,6 \\
$\quad<28 />45$ thn & 19 & 20,4 \\
Jenis Kelamin & & \\
$\quad$ Perempuan & 54 & 58,1 \\
$\quad$ Laki-laki & 39 & 41,9 \\
Pendidikan & & \\
SD & 4 & 4,3 \\
SMP & 6 & 6,5 \\
SMA & 43 & 46,2 \\
PT & 40 & 43,0 \\
Pekerjaan & & \\
IRT & 28 & 30,1 \\
PNS & 6 & 6,5 \\
Pegawai & 24 & 25,8 \\
Swasta & 20 & 21,5 \\
$\quad$ Wiraswasta & 15 & 16,1 \\
Karyawan & & \\
Penghasilan & & \\
$\quad \leq 3.296 .212,50$ & 29 & 31,2 \\
$\quad>3.296 .212,50$ & 64 & 68,8 \\
\hline
\end{tabular}

Berdasarkan Tabel 1 diketahui bahwa sebagian besar responden berada pada kategori usia ideal atau 28-45 tahun $(79,6 \%)$, berjenis kelamin perempuan $(58,1 \%)$, telah menempuh pendidikan SMA $(46,2 \%)$, bekerja sebagai Ibu rumah tangga $(30,1 \%)$, dan memiliki penghasilan kepala keluarga $>3.296 .212,50(68,8 \%)$.

Terdapat pernyataan yang ada pada kuesioner dengan tipe jawaban benar dan salah. Tabel 2 menunjukkan bahwa responden yang memiliki pengetahuan tentang jenis dan rating film, sebagian besar berada dalam kategori kurang $(49,5 \%)$. Responden yang mengijinkan anak menonton film yang mengandung unsur kekerasan adalah sebanyak 42 orang $(45,2 \%)$. Hal tersebut menunjukkan bahwa meskipun responden memiliki pengetahuan yang kurang tentang jenis dan rating film, masih banyak responden yang memberikan ijin kepada anak untuk menonton film yang mengandung unsur kekerasan. Hal tersebut menunjukkan bahwa Tabel 2 menunjukkan bahwa sebagian besar responden sangat mendukung anaknya menonton film yang mengandung unsur kekerasan $(84,9 \%)$. Dari 79 responden yang sikapnya sangat mendukung, terdapat $34,4 \%$ orang tua yang tidak mengijinkan anaknya menonton film yang mengandung unsur kekerasan dan $50,54 \%$ orang tua yang mengijinkan anaknya. Hal tersebut menunjukkan bahwa sebagian besar responden sangat mendukung dan mengijinkan anaknya menonton film yang mengandung unsur kekerasan.

Berdasarkan Tabel 2 menunjukkan bahwa, responden yang memiliki personal reference terhadap pengambilan keputusan dalam mengijinkan anak menonton film yang mengandung unsur kekerasan sejumlah 64 orang $(68,8 \%)$. Responden yang mengijinkan anak menonton film yang mengandung unsur kekerasan sebagian besar memilih orang tua sebagai personal reference $(41,9 \%)$. Hal tersebut menunjukkan bahwa, personal reference dapat menjadi faktor pendukung responden dalam mengambil keputusan.

Ketersediaan fasilitas pada penelitian ini didefinisikan dengan ketersediaan fasilitas di rumah yang menunjang anak untuk dapat mengakses film yang mengandung unsur kekerasan (superman rating PG-13). Ketersediaan fasilitas penunjang di rumah berupa televisi, DVD, computer, laptop, tv dengan channel berbayar dan fasilitas internet. Kepemilikan atas ketersediaan fasilitas penunjang tersebut dikategorikan menjadi dua kategori yaitu fasilitas terpenuhi dan tidak terpenuhi. Berdasarkan Tabel 2 diketahui sebagian besar responden memiliki fasilitas yang terpenuhi $(58,1 \%)$. Dari 54 responden yang memiliki fasilitas 
Tabel 2. Tabulasi Silang antara Pengetahuan, Sikap, Personal Reference, Ketersediaan Fasilitas, dan Budaya Keluarga pada Responden di SDN 3 Ketabang, Surabaya

\begin{tabular}{|c|c|c|c|c|c|c|}
\hline \multirow{3}{*}{ Pengetahuan } & \multicolumn{4}{|c|}{ Keputusan Orang tua } & \multirow{2}{*}{\multicolumn{2}{|c|}{ Total }} \\
\hline & \multicolumn{2}{|c|}{ Tidak Mengijinkan } & \multicolumn{2}{|c|}{ Mengijinkan } & & \\
\hline & $\mathbf{N}$ & $\%$ & $\mathbf{N}$ & $\%$ & $\mathbf{N}$ & $\%$ \\
\hline Kurang & 4 & 4,3 & 42 & 45,2 & 46 & 49,5 \\
\hline Cukup & 8 & 8,6 & 12 & 12,9 & 20 & 21,5 \\
\hline Baik & 23 & 24,7 & 4 & 4,3 & 27 & 29,0 \\
\hline Total & 35 & 37,6 & 58 & 62,4 & 93 & 100 \\
\hline \multicolumn{7}{|l|}{ Sikap } \\
\hline Sangat Tidak Mendukung & 0 & 0 & 0 & 0 & 0 & 0 \\
\hline Tidak Mendukung & 1 & 1,1 & 0 & 0 & 1 & 1,1 \\
\hline Mendukung & 2 & 2,2 & 11 & 11,8 & 13 & 14,0 \\
\hline Sangat Mendukung & 32 & 34,4 & 47 & 50,5 & 79 & 84,9 \\
\hline Total & 35 & 37,6 & 58 & 62,4 & 93 & 100 \\
\hline \multicolumn{7}{|l|}{ Personal Reference } \\
\hline Orang tua & 25 & 26,9 & 39 & 41,9 & 64 & 68,8 \\
\hline Kerabat & 4 & 4,3 & 10 & 10,8 & 14 & 15,1 \\
\hline Teman & 4 & 4,3 & 9 & 9,7 & 13 & 14,0 \\
\hline Teman & 4 & 4,3 & 9 & 9,7 & 13 & 14,0 \\
\hline Tetangga & 2 & 2,2 & 0 & 0 & 2 & 2,2 \\
\hline Total & 35 & 37,6 & 58 & 62,4 & 93 & 100 \\
\hline \multicolumn{7}{|l|}{ Ketersediaan Fasilitas } \\
\hline Tidak Terpenuhi & 29 & 31,2 & 10 & 10,8 & 39 & 41,9 \\
\hline Terpenuhi & 6 & 6,5 & 48 & 51,6 & 54 & 58,1 \\
\hline Total & 35 & 37,6 & 58 & 62,4 & 93 & 100 \\
\hline \multicolumn{7}{|l|}{ Budaya Keluarga } \\
\hline Rendah & 19 & 20,4 & 12 & 12,90 & 31 & 33,3 \\
\hline Tinggi & 16 & 17,2 & 46 & 49,5 & 62 & 66,7 \\
\hline Total & 35 & 37,63 & 58 & 62,4 & 93 & 100 \\
\hline
\end{tabular}

terhadap akses film yang mengandung unsur kekerasan, sebagian besar mengijinkan anak menonton film yang mengandung unsur kekerasan (54\%). Hal tersebut menunjukkan bahwa sebagian besar responden memiliki fasilitas yang terpenuhi dan mengijinkan anaknya menonton film yang mengandung unsur kekerasan.

Culture dalam hal ini adalah budaya yang ada dan berkembang di keluarga dan masyarakat khususnya di sekitar responden yang masih dipercaya dan dianut hingga saat ini dalam upaya pengambilan keputusan kepada anak terkait film yang mengandung unsur kekerasan. Culture dalam penelitian ini dikategorikan menjadi dua yaitu budaya di keluarga yang tinggi dan budaya keluarga yang rendah. Berdasarkan tabel 2, diketahui bahwa sebagian besar responden memiliki budaya keluarga yang tinggi $(66,7 \%)$. Dari 46 responden yang memiliki budaya keluarga yang tinggi, sebagian besar responden mengijinkan anak menonton film

Tabel 3. Hasil Uji Chi Square

\begin{tabular}{lc}
\hline Variabel & Nilai P \\
\hline Pengetahuan & 0,000 \\
Sikap & 0,096 \\
Personal Reference & 0,249 \\
Usia & 0,853 \\
Penghasilan & 0,000 \\
Ketersediaan Fasilitas & 0,000 \\
Budaya Keluarga & 0,002 \\
\hline
\end{tabular}


Tabel 4. Distribusi Judul Film Superhero dengan Rating PG-13 terhadap Keputusan Orang tua Mengijinkan Anak Menonton Film yang Mengandung Unsur Kekerasan di SDN Ketabang, Surabaya

\begin{tabular}{|c|c|c|c|c|c|c|c|}
\hline \multirow{3}{*}{ Judul Film } & & \multicolumn{4}{|c|}{ Keputusan Responden } & \multirow{2}{*}{\multicolumn{2}{|c|}{ Jumlah }} \\
\hline & & \multicolumn{2}{|c|}{ Tidak Mengijinkan } & \multicolumn{2}{|c|}{ Mengijinkan } & & \\
\hline & & $\mathbf{n}$ & $\%$ & $\mathbf{n}$ & $\%$ & n & $\%$ \\
\hline \multirow[t]{2}{*}{ Superman 2} & Tidak boleh & 30 & 32,3 & 19 & 20,7 & 49 & 52,7 \\
\hline & Boleh & 5 & 5,4 & 39 & 41,9 & 44 & 47,3 \\
\hline \multirow[t]{2}{*}{ Spiderman } & Tidak boleh & 29 & 31,2 & 7 & 7,5 & 36 & 38,7 \\
\hline & Boleh & 6 & 6,5 & 51 & 54,8 & 57 & 61,3 \\
\hline \multirow[t]{2}{*}{ Transformer } & Tidak boleh & 32 & 34,4 & 11 & 11,8 & 43 & 46,2 \\
\hline & Boleh & 3 & 3,2 & 47 & 50,5 & 50 & 53,8 \\
\hline \multirow[t]{2}{*}{ The Avengers } & Tidak boleh & 32 & 34,4 & 10 & 10,8 & 10 & 45,2 \\
\hline & Boleh & 3 & 3,2 & 48 & 51,6 & 51 & 54,8 \\
\hline \multirow[t]{2}{*}{ Avatar } & Tidak boleh & 34 & 36,6 & 18 & 19,4 & 52 & 55,9 \\
\hline & Boleh & 1 & 1,1 & 40 & 43,0 & 41 & 44,1 \\
\hline
\end{tabular}

yang mengandung unsur kekerasan (49,5\%). Hal tersebut menunjukkan bahwa sebagian besar responden memiliki budaya keluarga yang tinggi dan mengijinkan anaknya menonton film yang mengandung unsur kekerasan.

Uji chi square digunakan untuk mengetahui faktor yang berhubungan dengan keputusan orang tua dalam mengijinkan anak menonton film yang mengandung unsur kekerasan. Hasil uji bivariat berdasarkan variabel bebas dengan variabel terikat dapat dilihat pada Tabel 3 Pada Tabel 3 menunjukkan bahwa ada hubungan antara variabel pengetahuan, penghasilan kepala keluarga, ketersediaan fasilitas, dan budaya keluarga terhadap keputusan orang tua dalam mengijinkan anak menonton film yang mengandung unsur kekerasan.

Hasil uji chi square menunjukkan bahwa variabel pengetahuan $(\mathrm{p}=0,000)$, ketersediaan fasilitas $(p=0,000)$, penghasilan kepala keluarga $(p=0,000)$, dan culture keluarga $(p=0,002)$ berhubungan secara signifikan terhadap keputusan orang tua dalam mengijinkan anak menonton film yang mengandung unsur kekerasan. Sedangkan variabel sikap $(\mathrm{p}=0,096)$, personal reference $(\mathrm{p}=0,249)$, dan umur $(\mathrm{p}=0,853)$ tidak berhubungan secara signifikan terhadap keputusan orang tua dalam mengijinkan anak menonton film yang mengandung unsur kekerasan.

Berdasarkan tabel 4 diketahui bahwa judul film dengan rating PG-13 yang dimaksud dalam penelitian ini adalah Superman 2, Spiderman, Transformer, The Avengers, dan Avatar. Tabulasi silang dalam Tabel 4 menunjukkan bahwa judul film yang sebagian besar tidak dibolehkan untuk ditonton adalah Superman $2(52,7 \%)$ dan Avatar (55,9\%). Namun, dari 49 responden yang tidak memperbolehkan film Superman 2 ditonton, 19 responden diantaranya memberikan ijin anaknya untuk menonton film tersebut (20,7\%). Namun, dari 52 responden yang tidak memperbolehkan film Avatar ditonton, 18 responden diantaranya memberikan ijin anaknya untuk menonton film tersebut $(19,4 \%)$. Hal tersebut menunjukkan bahwa masih ada beberapa responden yang mengijinkan anak untuk menonton film yang mengandung unsur kekerasan meskipun sebenarnya tidak memperbolehkan anaknya menonton film tersebut. Sedangkan judul film yang sebagian besar dibolehkan untuk ditonton adalah film Spiderman (61,3\%), film The Avengers $(54,8 \%)$, dan Transformer $(53,8 \%)$.

Variabel yang Berhubungan dengan Keputusan Mengijinkan Anak Menonton Film yang Mengandung Unsur Kekerasan

Penghasilan pada penelitian ini merupakan jumlah nominal yang diperoleh responden dalam sebulan untuk mencukupi kebutuhan hidup sehari-hari. Pada penelitian ini, jika pendapatan kurang dari Upah Minimum Kota (UMK) dikategorikan tingkat pendapatan rendah, dan jika 
pendapatan sama atau lebih dari UMK dikategorikan tingkat pendapatan tinggi. Penghasilan juga merupakan salah satu faktor yang dapat berpengaruh terhadap perilaku seseorang atau kelompok masyarakat.

Sebagian besar responden memiliki penghasilan yang tinggi atau lebih dari UMK Rp. 3.296.212,50 (68,8\%). Dari hasil penelitian juga diketahui bahwa sebagian besar orang tua yang mengijinkan anaknya menonton film yang mengandung unsur kekerasan memiliki penghasilan yang tinggi. Hasil uji chi square menunjukkan bahwa terdapat hubungan yang signifikan antara penghasilan kepala keluarga dengan keputusan orang tua mengijinkan anak menonton film yang mengandung unsur kekerasan $(\mathrm{p}=0,000)$. Hasil ini sejalan dengan penelitian yang dilakukan Wonsun Shin (2010) tentang The Role of Parental Mediation in Children's Consumer Socialization on the Web. Penelitian tersebut menemukan bahwa pendapatan keluarga berkaitan erat dengan gaya orang tua dalam mengawasi konten yang dilihat anak di dunia maya. Orang tua dengan anak berusia lebih muda, memiliki penghasilan kepala keluarga yang tinggi, dan sikap negatif terhadap situs komersial yang menargetkan anak-anak lebih cenderung terlibat dalam pengawasan yang tinggi.

Pengetahuan merupakan salah satu faktor pada diri seseorang yang dapat memengaruhi suatu tindakan atau perilaku. Pengetahuan dalam penelitian diukur dengan beberapa pernyataan mengenai pemahaman responden tentang jenis dan rating film yang mengandung unsur kekerasan. Berdasarkan hasil penelitian diketahui bahwa sebagian besar responden memiliki pengetahuan yang kurang terhadap jenis dan rating film (49,5\%). Hasil tersebut sesuai dengan laporan penelitian yang dipublikasikan oleh ofcom.urg.uk pada Oktober 2014 tentang Children and Parents: Media Use and Attitudes Report. Laporan tersebut menemukan bahwa sebagian besar orang tua tidak peduli dengan konten yang ada di televisi, termasuk orang tua dengan anak yang berusia $8-11$ tahun $(66 \%)$. Hasil penelitian tersebut juga menemukan bahwa hanya sebagian kecil orang tua dengan anak berusia 8-11 tahun yang memperhatikan jenis konten di televisi, seperti penggunaan bahasa kasar (15\%), seksualitas (13\%), kekerasan (8\%), dan diskriminasi (2\%). Penelitian Gentile dkk., dalam buku Media Violence and Children juga menyebutkan bahwa orang tua yang membatasi tayangan televisi pada anak memiliki peringkat yang lebih baik di dalam kelas, tidur yang cukup, dan memiliki perilaku yang kurang serta lebih pro-sosial. Berdasarkan penelitian tersebut disebutkan bahwa orang tua perlu memiliki pengetahuan mengenai konten dan rating televisi agar dapat membatasi tayangan televisi yang dapat ditonton oleh anak-anak.

Kurangnya pengetahuan orang tua/ wali murid mengenai jenis dan rating film disebabkan oleh ketidaktahuan mereka mengenai makna dari simbol rating. Penelitian Gentile et al., pada tahun 2011 menyebutkan bahwa sebagian besar orang tua tidak setuju dengan rating film, karena rating film seringkali tidak akurat dalam menjelaskan konten film. Analisis konten film yang dilakukan pada 1.332 TV bahkan ditemukan bahwa konten film lebih banyak mengandung unsur yang berbahaya bagi remaja dibandingkan dengan apa yang tertera pada rating film.

Hasil uji chi square menunjukkan bahwa ada hubungan yang signifikan antara pengetahuan responden dengan keputusan dalam mengijinkan anak menonton tayangan film yang mengandung unsur kekerasan $(\mathrm{p}=$ 0,000). Hasil tersebut menunjukkan bahwa seseorang yang memiliki pengetahuan tentang jenis dan rating film yang baik akan memiliki dasar atau acuan yang digunakan untuk membuat keputusan dalam memberikan atau tidak memberikan ijin anak dalam menonton tayangan film yang mengandung unsur kekerasan.

Resources atau sumber daya yang tersedia merupakan pendukung untuk terjadi nya suatu perilaku seseorang atau kelompok masyarakat. Hasil penelitian menunjukkan bahwa sebagian besar responden memiliki fasilitas yang terpenuhi dalam mengakses film $(58,1 \%)$. Ketersediaan fasilitas penunjang di rumah diantaranya berupa televisi, DVD, komputer, laptop, televisi dengan channel berbayar, dan fasilitas 
internet. Terpenuhinya fasilitas di rumah cenderung membuat anak lebih mudah mengakses film yang mengandung unsur kekerasan dibandingkan dengan responden yang memiliki fasilitas yang terbatas. Adanya fasilitas yang terpenuhi juga dapat memotivasi anak mengakses film secara bebas. (Setyawan, 2015) Hasil uji chi square didapatkan bahwa terdapat hubungan yang signifikan antara ketersediaan fasilitas di rumah terhadap keputusan orang tua mengijinkan anak menonton film yang mengandung unsur kekerasan $(\mathrm{p}=0,000)$. Hasil tersebut sejalan dengan teori Lawrence Green dalam buku Notoatmodjo (2012) yang menyebutkan bahwa faktor pemungkin (enabling factor) seperti sarana dan prasarana atau fasilitas dapat menyebabkan seseorang melakukan perilaku tertentu di dalam keluarga. Keluarga yang fasilitasnya terpenuhi cenderung mengijinkan anaknya untuk menonton film yang mengandung unsur kekerasan seperti film superhero dengan rating PG-13. Hal ini sejalan dengan penelitian Browne (2005) yang menyebutkan bahwa semakin lengkap fasilitas penunjang yang dimiliki suatu keluarga, maka akan semakin mengarahkan anggota keluarga tersebut untuk menjadi keluarga konsumtif terhadap tayangan yang mengandung kekerasan.

Culture adalah budaya yang masih berkembang dan dipercaya oleh keluarga dalam upaya pengambilan keputusan kepada anak terkait ijin menonton film yang mengandung unsur kekerasan. Budaya terbentuk dalam waktu yang lama sebagai akibat dari kehidupan bermasyarakat. Budaya juga terbentuk dari banyak unsur yang rumit, seperti sistem agama, politik, adat istiadat, bahasa, dll. Budaya selalu berubah, baik lambat ataupun cepat sesuai dengan perkembangan jaman. (Notoadmojo, 2010) Organisasi Kesehatan Dunia atau WHO menjelaskan bahwa terdapat empat alasan utama yang menyebabkan seseorang dapat berperilaku, salah satunya adalah kebudayaan (culture).

Perilaku seseorang juga dapat ditentukan oleh konsep diri (self concept) dari individu tersebut. Secara tidak langsung, konsep diri seseorang cenderung menentukan apakah seseorang akan menerima keadaannya seperti apa adanya atau berusaha untuk mengubah perilakunya. Penilaian orang tua terhadap budaya terkait keputusan mengijinkan anaknya menonton film yang mengandung unsur kekerasan di SDN Ketabang Surabaya dipengaruhi oleh konsep diri dari masing-masing orang tua anak itu sendiri. Konsep diri orang tua ditentukan oleh tingkat kepercayaan dan tingkat ketidak kepercayaan yang dirasakan oleh orang tua. Sehingga dapat disimpulkan bahwa sosio-budaya di keluarga responden tidak memengaruhi secara langsung keputusan orang tua dalam mengijinkan anaknya menonton film yang mengandung unsur kekerasan.

Dari hasil penelitian dapat diketahui bahwa sebagian besar responden memiliki budaya yang tinggi di keluarga $(66,7 \%)$. Hasil uji chi square menunjukkan bahwa terdapat hubungan yang signifikan antara budaya keluarga terhadap keputusan orang tua mengijinkan anak menonton film yang mengandung unsur kekerasan $(p=0,002)$. Hasil ini sejalan dengan pendapat yang dikemukakan oleh Soekidjo Notoadmojo (2010) yang menyebutkan bahwa sosio budaya biasanya dapat berpengaruh terhadap terbentuknya perilaku seseorang.

Variabel yang Tidak Berhubungan dengan Keputusan Mengijinkan Anak Menonton Film yang Mengandung Unsur Kekerasan

Usia merupakan lama hidup responden dihitung berdasarkan tahun lahir hingga tahun penelitian. Usia merupakan salah satu faktor demografi yang dapat memengaruhi cara berpikir responden dalam memilih keputusan mengijinkan anak menonton film yang mengandung unsur kekerasan. Hasil penelitian menunjukkan bahwa sebagian besar responden berada pada kategori usia ideal (28-45 tahun). Kategori tersebut termasuk dalam kategori umur masa dewasa muda. (Hurlock, 2011) Usia dewasa muda merupakan usia optimal seseorang untuk dapat menerima informasi sehingga berpengaruh terhadap pola pikir orang tua untuk melakukan perilaku. Dari hasil penelitian ini juga diketahui bahwa sebagian besar responden yang mengijinkan anaknya 
menonton film yang mengandung unsur kekerasan berada pada kategori usia ideal (28-45 tahun).

Hasil uji chi square menunjukkan bahwa tidak terdapat hubungan yang signifikan antara usia dengan keputusan responden dalam mengijinkan anak menonton tayangan film yang mengandung unsur kekerasan $(\mathrm{p}=0,853)$. Tidak adanya hubungan antar variabel usia dengan keputusan responden dalam mengijinkan anak menonton film yang mengandung unsur kekerasan dapat dipengaruhi oleh faktor lain dalam penelitian seperti pendidikan, pengetahuan, sikap, personal reference, ketersediaan fasilitas, dan budaya dalam keluarga.

Sebagian besar responden memiliki sikap yang sangat mendukung terhadap pengawasan tontonan televisi pada anak $(84,9 \%)$. Sikap mendukung tersebut berupa pemantauan terhadap tayangan yang ditonton, pendampingan anak yang menonton film khususnya film superhero, dan penentuan jenis tayangan televisi yang boleh dan tidak boleh di tonton oleh anak. Sikap mendukung tersebut muncul sebagai akibat dari adanya kekhawatiran orang tua dengan pengaruh tayangan televisi terhadap perkembangan anak. Kekhawatiran tersebut sejalan dengan penelitian Brown dan Hamilton tahun 2005 menyebutkan bahwa tayangan kekerasan, baik berupa gambar, film, video, atau pada games di komputer dapat berdampak jangka pendek pada pikiran, emosi, dan perilaku agresif pada anak, khususnya anak laki-laki. Penelitian Ojo et al tentang Parental Perception And Attitude To Children's Violent Acts In Ife Central Local Government Area Secondary Schools Ojo juga menemukan bahwa tayangan kekerasan pada film memiliki pengaruh terhadap tindakan kekerasan yang terjadi di sekolah $(85 \%)$.

Sikap sangat mendukung terhadap adanya pengawasan tayangan televisi pada anak dapat berperan dalam mengurangi dampak buruk tayangan film terhadap perkembangan anak. Orang tua dengan sikap positif cenderung memberikan pengawasan terhadap jenis film atau tayangan yang ditonton oleh anak-anak. Pengawasan orang tua berupa menemani anak menonton televisi, diskusi tentang film yang ditonton, mengawasi pilihan film yang ditonton oleh anak diketahui sebagai cara efektif dalam mengurangi dampak buruk tayangan film yang mengandung unsur kekerasan terhadap perkembangan anak. (Austin et al. 1999; Nathanson 2001) Penelitian Shaleh et al tentang Effects of Watching Violence Movies on the Attitudes Concerning Aggression among Middle Schoolboys (13-17 years old) at International Schools in Kuala Lumpur, Malaysia tahun 2009 menemukan bahwa hanya sebagian kecil orang tua yang melakukan diskusi tentang film dengan anak mereka $(11,6 \%)$, dan hanya sebagian kecil orang tua yang memantau anak mereka saat menonton televisi (17,1\%). Penelitian Kaiser (2010) bahkan menemukan bahwa anak yang berusia lebih dari 7 tahun cenderung tidak pernah menonton televisi bersama orang tua mereka.

Hasil uji chi square menunjukkan bahwa tidak terdapat hubungan yang signifikan antara sikap dengan keputusan responden dalam mengijinkan anak menonton tayangan film yang mengandung unsur kekerasan $(\mathrm{p}=0,096)$. Hasil penelitian ini tidak sejalan dengan teori dari ahli psikologi, LaPierre yang menyatakan bahwa terdapat hubungan yang kuat antara sikap dan perilaku karena semakin kuat sikap seseorang terhadap sesuatu, maka akan semakin kuat sikap tersebut untuk diwujudkan dalam bentuk perilaku. Hasil penelitian ini menunjukkan bahwa meskipun responden memiliki sikap yang sangat mendukung terhadap pengawasan tontonan televisi pada anak, namun, ada beberapa faktor yang dapat menyebabkan responden tidak melakukan pengawasan secara optimal, diantaranya seperti ketidaktahuan orang tua terhadap rating film atau kesibukan orang tua dalam bekerja. Tidak adanya hubungan antar variabel sikap dengan keputusan responden dalam mengijinkan anak menonton film yang mengandung unsur kekerasan juga dapat dipengaruhi oleh faktor lain dalam penelitian seperti usia, pendidikan, pengetahuan, personal reference, ketersediaan fasilitas, dan budaya dalam keluarga.

Perilaku individu lebih banyak dipengaruhi oleh orang-orang yang dianggap 
penting. Apabila seseorang itu dianggap penting untuknya, maka apa yang orang tersebut katakan atau perbuatan cenderung untuk dicontoh. Orang-orang yang dianggap penting ini sering disebut sebagai personal reference atau kelompok referensi. (Notoatmodjo, 2010) Personal reference dalam penelitian ini dibagi ke dalam empat kategori, yang terdiri orang tua, kerabat, teman, dan tetangga.

Berdasarkan hasil penelitian, sebagian besar responden menjadi kan orang tua mereka sebagai personal reference dalam pengambilan keputusan $(68,8 \%)$. Hasil ini sejalan dengan studi Joan dan Tanya tentang Parents'Attitudes and Beliefs: Their Impact on Children's Development pada Desember 2014 yang menunjukkan bahwa seseorang cenderung meniru perilaku orang tua karena mereka mempelajari tentang bagaimana cara orang tua mereka mendidik mereka.

Hasil uji chi square menunjukkan bahwa tidak terdapat hubungan yang signifikan antara personal reference dengan keputusan responden dalam mengijinkan anak menonton tayangan film yang mengandung unsur kekerasan $(p=0,249)$. Hasil penelitian ini tidak sejalan dengan penelitian Bearden (1982) yang menyatakan bahwa personal references faktor yang tergabung dalam kelompok referensi mempunyai pengaruh yang signifikan terhadap perilaku/tindakan seseorang. Menurut Bearden setiap individu mempunyai kecenderungan untuk berperilaku atau mempunyai harapan agar individu itu sama dengan kelompoknya setelah mendapat pengaruh dari kelompok referensi. Tidak adanya hubungan antar variabel usia dengan keputusan responden dalam mengijinkan anak menonton fil yang mengandung unsur kekerasan dapat dipengaruhi oleh faktor lain dalam penelitian seperti pendidikan, pengetahuan, sikap, usia, ketersediaan fasilitas, dan budaya dalam keluarga.

\section{KESIMPULAN}

Berdasarkan hasil penelitian dan analisis pembahasan yang dilakukan mengenai faktor-faktor yang berhubungan dengan keputusan orang tua dalam mengijinkan anak menonton tayangan film yang mengandung unsur kekerasan, diketahui bahwa sebagian besar responden adalah perempuan $(58,1 \%)$, berusia $28-45$ tahun $(79,6 \%)$, bekerja sebagai Ibu Rumah Tangga (30,1\%), dan kepala keluarga memiliki penghasilan yang tinggi $(68,8 \%)$. Dalam kaitannya terhadap keputusan orang tua mengijinkan anak menonton film yang mengandung unsur kekerasan, responden memiliki pengetahuan yang kurang $(49,47 \%)$, sikap yang kurang mendukung $(84,94 \%)$, orang tua sebagai personal reference dalam mengambil keputusan $(68,82 \%)$, fasilitas yang tidak terpenuhi $(52,69 \%)$, dan culture keluarga yang tinggi $(69,9 \%)$. Sebagian besar responden mengijinkan anak menonton film yang mengandung unsur kekerasan $(62,4 \%)$.

Hasil uji bivariat dengan chi square menunjukkan bahwa variabel pengetahuan, ketersediaan fasilitas, penghasilan kepala keluarga, dan culture keluarga berhubungan secara signifikan terhadap keputusan orang tua dalam mengijinkan anak menonton film yang mengandung unsur kekerasan. Sedangkan variabel sikap, personal references, dan umur tidak berhubungan secara signifikan terhadap keputusan orang tua dalam mengijinkan anak menonton film yang mengandung unsur kekerasan.

Berdasarkan simpulan yang diperoleh, berikut adalah beberapa saran yang dapat dilakukan untuk mengantisipasi pengaruh buruk media televisi terhadap perkembangan anak:

Orang tua perlu mengetahui jenis dan rating film yang dapat ditonton oleh anakanak sesuai perkembangannya.

Orang tua sebaiknya mendampingi anak saat menonton televisi. Tujuannya adalah agar orang tua dapat mengawasi apa yang ditonton oleh anak, serta dapat melakukan diskusi dengan anak terhadap film yang ditonton.

Orang tua perlu membatasi jumlah waktu anak menonton televisi dan ajak anak melakukan aktivitas lain, seperti menikmati alam dan lingkungan, bersosialisasi dengan teman seusianya, atau orang tua dapat memperkenalkan anak dengan hobi baru yang menyenangkan. 


\section{DAFTAR PUSTAKA}

American Academy of Pediatrics Council on Communications and Media. 2009. Policy Statement-Media Violence. Pediatrics, 124 (5), 1495-1503.

Austin, E.W., Y. Fujioka, P. Bolls, and J. Engelbertson. 1999. How and Why Parents Take on the Tube. Journal of Broadcasting \& Electronic Media 43: 175-192.

Bandura,A.\&S.A. Ross. 1963. AComparative Test of the statue Envy, Social Power and Secondary Reinforcement Theories of Identificatory Learning. Journal of Abnormal \& Social Psychology, 67, hal. 527-539.

Browne. 2005. The Influence of Violent Media on Children and Adolescents: a Public Health Approach. Centre for Forensic and Family Psychology, School of Psychology, University of Birmingham, UK.

Brown dan Hamilton. 2005. The Influence of Violent Media on Children and Adolescents: a Public Health Approach.

Gentile, D.A., Maier, J.A., Hasson, M.R., \& de Bonetti, B.L. 2011. Parents Evaluation of Media Ratings a Decade After the Television Ratings were Introduced. Pediatrics, 128(1), 36-44.

Guntarto, B. dkk. 2000. Growing Up with TV. Singapore: AMIC.

Hernawati, R \& Palapah, M,A,O. 2011. Televisi dalam kehidupan Anak. Prosiding Seminar Nasional Penelitian dan PKM: Sosial, Ekonomi, dan Humaniora.

Hurlock, Elizabeth. B. 2001 Psikologi Perkembangan: Suatu pendekatan sepanjang rentang.

Joan dan Tanya. 2014. Parents Attitudes and Beliefs: Their Impact on Children's Development. Encyclopedia of Early Child Development.
Kaiser Family Foundation: Parents, Children, and Media. 2010. Report of the Kaiser Family Foundation.

Laporan Komnas Perlindungan Anak. 2006.

LaPiere, R.T. 2010. Attitude vs Action. International Journal of Epidemiology. doi:10.1093/ije/dyp39.

Notoatmodjo S. 2010. Metodologi Penelitian Kesehatan. Jakarta: Rineka Cipta.

Nathanson, A., \& M. Yang. 2001. Parents Versus Peers: Exploring the Significance of Peer Mediation of Antisocial Television. Communication Research 28: 251-275.

Notoatmodjo S. 2012. Promosi Kesehatan dan Ilmu Perilaku. Jakarta: Rineke Cipta.

Ofcom. 2014. Children and Parents: Media Use and Attitudes Report.

Ojo, et al. 2011. Parental Perception and Attitude to Children's Violent Acts in Ife Central Local Government Area Secondary Schools. Vol. 4, No. $1 \& 2$.

Safitri, dkk. 2013. Hubungan antara Pola Asuh Orang Tua dengan Tingkat Depresi Remaja di SMK 10 November Semarang. Jurnal Keperawatan Jiwa Vol. 1 No. , Mei 2013.

Setyawan. 2015. Hubungan antara Ketersediaan Belajar di Rumah dengan Motivasi Belajar Peserta Kelas X. Universitas Nusantara PGRI Kediri.

Shaleh, et al. Effects of Watching Violence Movies on the Attitudes Concerning Aggression among Middle Schoolboys (13-17 years old) at International Schools in Kuala Lumpur, Malaysia. European Journal of Scientific Research. ISSN 1450-216X Vol.38 No.1, Desember 2009, pp. 141-156.

Wansun Shin. 2010. The Role of Parental Mediation in Children's Consumer Socialization on the Web. 